\title{
THE RECORD OF AVETOICHNUS LUISAE UCHMAN \& RATAZZI, 2011 IN THE IBERIAN PENINSULA: FACIES RELATIONS AND PALAEOENVIRONMENTAL IMPLICATIONS
}

\author{
Francisco J. RODRÍGUEZ-TOVAR ${ }^{1, *}$ \& Alfred \\ $U C H M A N^{2}$
}

${ }^{1}$ Departamento de Estratigrafía y Paleontología, Facultad de Ciencias, Universidad de Granada, E-18002 Granada, Spain; fjrtovar@ugr.es

${ }^{2}$ Institute of Geological Sciences, Jagiellonian University, PL-30-063 Cracow, Poland; alfred.uchman@uj.edu.pl

* Corresponding author

Rodríguez-Tovar, F. J. \& Uchman, A. 2012. The record of Avetoichnus luisae Uchman \& Ratazzi, 2011 in the Iberian Peninsula: facies relations and palaeoenvironmental implications. [Registro de Avetoichnus luisae Uchman \& Ratazzi, 2011 en la Península Ibérica: relación con las facies e implicaciones paleoambientales]. Revista Española de Paleontología, 27 (1), 67-74. ISSN 0213-6937.

\begin{abstract}
Recently, the new ichnogenus Avetoichnus and the corresponding type ichnospecies Avetoichnus luisae Uchman \& Ratazzi, 2011 were defi ned mainly based on Cenozoic specimens from deep-sea sediments from the Alpine realm (Italy and Poland). Avetoichnus luisae is a complex trace fossil, horizontal or subhorizontal, with a helical spiral string around a simple, straight or slightly curved core. The structure is interpreted as a non-graphoglyptid agrichnion generated probably by polychaetes, and less probably by enteropneusts. Here, complementary occurrences in Palaeocene and Eocene sediments from the North of Spain (Zumaia and Gorrondatxe sections), representing the record of this ichnoespecies in the Iberian Peninsula, are described. The studied specimens reveal a narrow relationship with deep-sea settings, characterized by moderately oligotrophic conditions, during relatively high sea-levels, inducing a microbial gardening behaviour of the producer. Obtained data and interpretations corroborate and complement the characterization and interpretation of the recently defined ichnotaxa.
\end{abstract}

Keywords: Avetoichnus luisae, Palaeocene, Eocene, Zumaia, Gorrondatxe.

\section{RESUMEN}

Recientemente, el icnogénero Avetoichnus y su correspondiente icnoespecie tipo Avetoichnus luisae Uchman \& Rattazzi, 2011 han sido defi nidos en base, fundamentalmente, a registros cenozoicos de Italia y Polonia procedentes de sedimentos marinos profundos. Avetoichnus luisae es una traza compleja, horizontal o subhorizontal, con una estructura helicoidal (espiral) atravesada en su parte central por un tubo simple, recto o ligeramente curvado. Es interpretada como una traza de cultivo/trampa (agrichnia) no grafoglíptida, generada probablemente por poliquetos y en menor medida por enteropneustos. En este trabajo se describe material complementario procedente de sedimentos del Paleoceno y Eoceno del Norte de España (perfiles de Zumaia y Gorrondatxe), que representa el primer registro de esta icnoespecie en la Península Ibérica. Los ejemplares estudiados revelan una estrecha relación con ambientes marinos profundos, caracterizados por condiciones oligotrófi cas moderadas, en situaciones de nivel relativo del mar alto, que determinan un comportamiento de cultivo de microorganismos por parte del organismo que las produce. Los datos e interpretaciones obtenidos corroboran y complementan la caracterización e interpretación del icnotaxón definido.

Palabras clave: Avetoichnus luisae, Paleoceno, Eoceno, Zumaia, Gorrondatxe.

https://doi.org/10.7203/sjp.27.1.18095 


\section{INTRODUCTION}

The ichnospecies Avetoichnus luisae Uchman \& Ratazzi, 2011, has been defined, mainly based on the record of specimens from deep-sea Cenozoic sediments of the Alpine realm (Italy and Poland) (Uchman \& Ratazzi, 2011). The trace fossil, interpreted as a non-graphoglyptid midtier complex agrichnion, corresponds to a horizontal or subhorizontal structure, with a helical spiral string around a simple, straight or slightly curved core. Together with the specimens from the Aveto Formation in the Apennines (northwestern Italy), and the Bystrica Formation in the Carpathians (southern Poland), punctual occurrences in Turkey and Spain have been considered.

The specimens collected in the North of Spain (Zumaia and Gorrondatxe sections) prove especially informative to complement the description and interpretation of this new complex trace fossil. The aim of this paper is to offer a detailed presentation of the record of Avetoichnus luisae in the Iberian Peninsula, focusing on facies relationships and palaeoenvironmental implications.

\section{GEOLOGICAL SETTING}

The studied specimens of Avetoichnus luisae at the Iberian Peninsula were collected in uppermost Palaeocene and lowermost Eocene sediments from the Zumaia and Gorrondatxe sections (Basque Country, northern Spain) (Fig. 1).

\section{THE ZUMAIA SECTION}

The Zumaia section is located along the coast between the cities of Bilbao and San Sebastian (northern Spain; N43ำ17.98', W002'15.63’; Figs 1, 2, 4). The studied Palaeocene-Eocene boundary interval, included in a continuous succession from the lower Santonian through the uppermost lower Eocene, consists of rhythmic alternations of hemipelagic limestones, marly limestones and marls, with numerous intercalations of thin-bedded turbidites (see Baceta et al., 2000, 2004).

The upper $6 \mathrm{~m}$ of the Palaeocene are composed of alternating grayish to greenish hemipelagic limestones, marly limestones and marls, with intercalations of numerous thin-bedded turbidites and the presence of glauconite (Fig. 4). The uppermost Palaeocene consists of a hemipelagic limestone unit 80-cm-thick (the "green" limestone due to its glauconite content), including a 4-cm-thick carbonate turbidite bed (Pujalte et al., 1998; Schmitz et al., 2000; Dinarès-Turell et al., 2002) (Fig. 4). Above it, in the lowermost Eocene, a 35-cm-thick marl bed, overlain by a 4-m-thick interval of reddish claystones and silty claystones (the "siliciclastic unit" in Schmitz et al., 2000), is recognized (Fig. 4).

\section{THE GORRONDATXE SECTION}

The Gorrondatxe section is located just northwest of Bilbao (Biscay Province, Basque Country, Spain; N43 22' 46”, W300’51”; Figs 1, 3, 5). The 700-m-thick analyzed
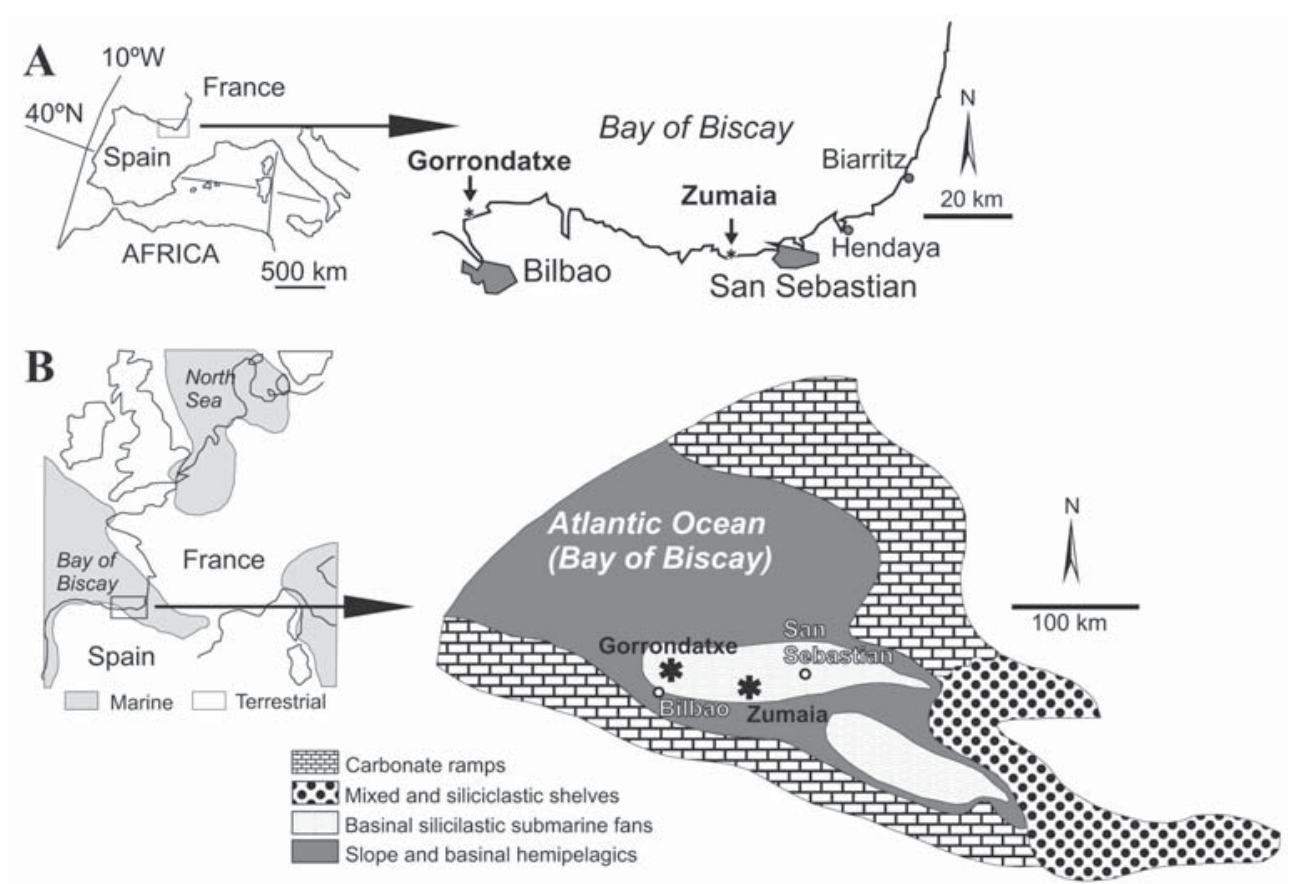

Figure 1. (A) Geographical location of the Zumaia and Gorrondatxe sections. (B) Palaeocene palaeogeography of the Pyrenean Basin showing location of the Zumaia and Gorrondatxe sections. 

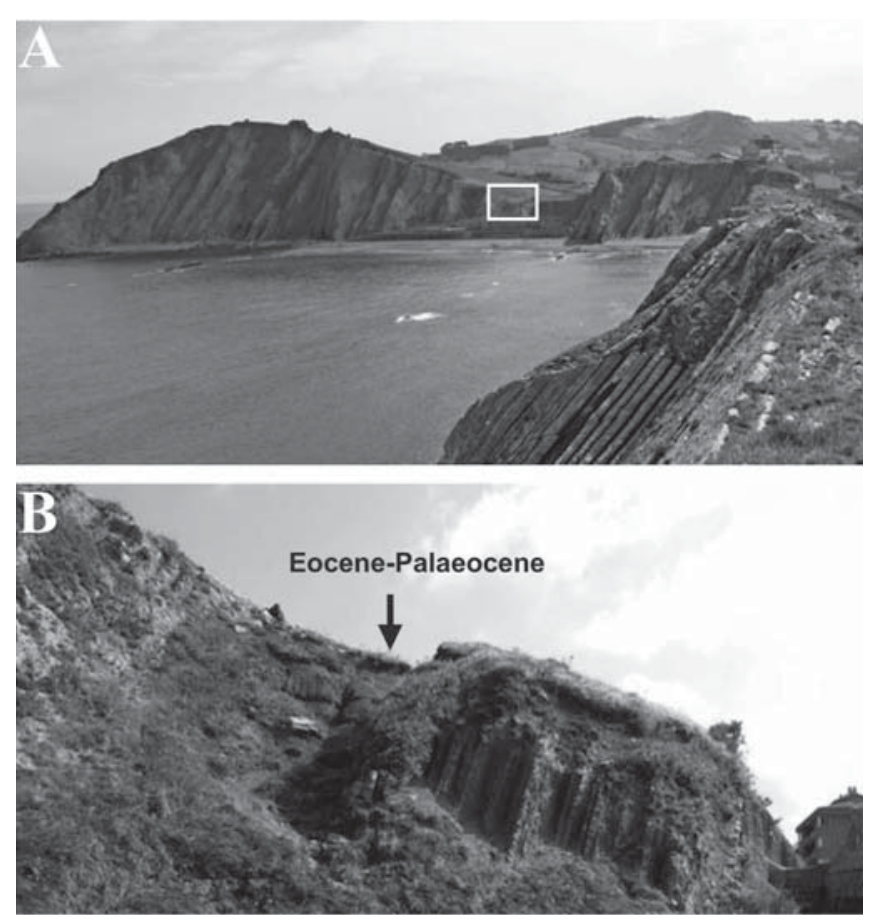

Figure 2. Outcrop photographs of the Zumaia section, showing panoramic view (A) and the detailed studied succession (B).

interval, exposed along the Gorrondatxe beach and corresponding to the middle part of the Eocene succession, is part of a 2300-m-thick lower Ypresian to upper Lutetian (Lower-Middle Eocene) succession that extends from the village of Sopela to the Galea Cape (Orue-Etxebarria et al., 1984; Bernaola et al., 2006; Payros et al., 2006, 2007).

The 700m-thick succession is composed of alternating pelagic limestones and marls, interspersed with thinbedded $(<10-15 \mathrm{~cm})$ siliciclastic turbidites and thickbedded mixed calciclastic-siliciclastic turbidites (Payros et al., 2006). Based on semiquantitative estimation of the vertical variations in turbidite abundance, six distinct intervals with variable amounts of turbidites have been differentiated (Payros et al., 2006, 2007). The "turbidite-poor" intervals are characterized by a turbidite content that rarely exceeds $20 \%$, with average values being lower than $10 \%$, while the "turbidite-rich" intervals show a turbidite content of $10 \%-80 \%$, and averaging $>20 \%$. The studied Avetoichnus luisae are recorded in the $2^{\text {nd }}$ turbidite-poor interval, at the base of the succession, mainly characterized by alternations of pelagic limestones and marls, turbidites commonly being just a few millimetres thick (Payros et al., 2009; Fig. 5).

Numerous sedimentological, sequence stratigraphic, cyclostratigraphic, magnetostratigraphic and palaeontological studies have been previously conducted in the succession; including the recent definition of the GSSP for the base of the Lutetian Stage (Early-Middle Eocene boundary) (see Molina et al., 2011 for a detailed review).
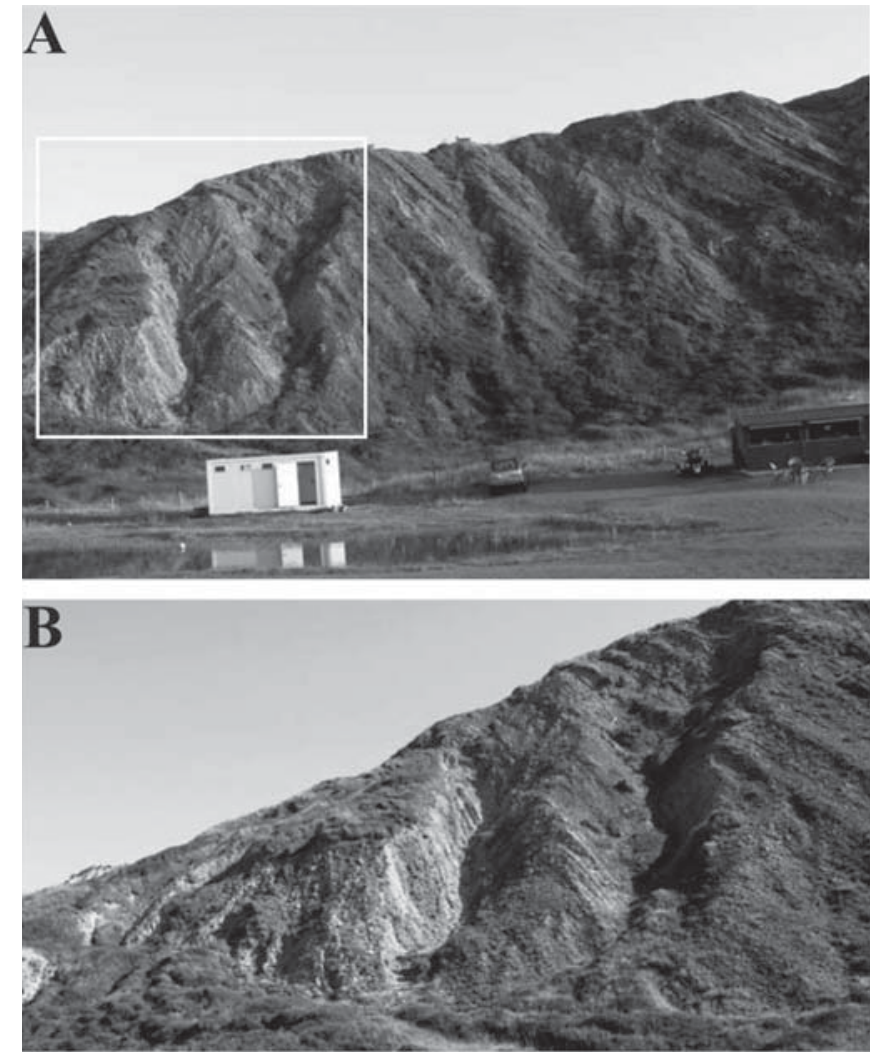

Figure 3. Outcrop photographs of the Gorrondatxe section, showing panoramic view (A) and the detailed studied succession (B).

\section{TRACE FOSSIL ANALYSIS}

The new ichnospecies Avetoichnus luisae Uchman \& Rattazzi, 2011 refers to a minute complex trace fossil, mostly horizontal to subhorizontal, characterized by a helical spiral structure, with a simple, straight or slightly curved central core (Uchman \& Rattazzi, 2011). Specimens are mostly up to $25 \mathrm{~mm}$, but rarely up to $42 \mathrm{~mm}$ long, and 2-4 mm, yet exceptionally up to $6 \mathrm{~mm}$ wide. This trace fossil appears characteristically as two rows of oval or circular dots (1.0-2.5 mm in diameter) arranged alternatively along a central, horizontal to subhorizontal axis, representing horizontal sections of a horizontal helical spiral. Moreover, it presents a zigzag appearance, another expression of a horizontal section. The number of whorls in the helical spiral is between 6 and 10, exceptionally up to 20, 2-3 mm apart from each other (see Uchman \& Rattazzi, 2011, for a detailed description).

The new ichnotaxon was based in the analysis of 21 Cenozoic specimens, collected from the fine-grained part of turbidite beds or in shales or marls, or at the transition from turbiditic sandstone to shale or marl from the Apennines (Italy) and the Carpathians (Poland), and complementary observations obtained from northern Spain and 


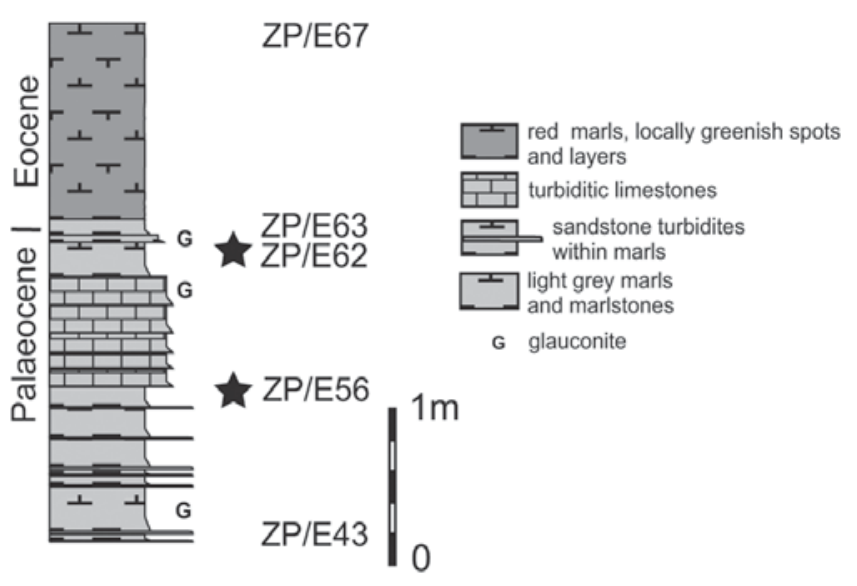

Figure 4. Bed-by-bed detailed log of the uppermost Palaeocenelowermost Eocene interval at the Zumaia section, showing occurrences of Avetoichnus luisae specimens (starts).

northern Turkey. A stratigraphic range of uppermost Palaeocene-Lower Oligocene has been proposed.

Avetoichnus luisae co-occurs with diverse trace-fossils, such as Chondrites, Planolites, Thalassinoides and Zoophycos, as well as with trace fossils typical of the Nereites ichnofacies, including Nereites, Paleodictyon, and Spirorhaphe. In view of cross-cutting relationships, Avetoichnus luisae is interpreted as occupying a mid-tier, at more or less the same level as Planolites and Palaeophycus, and shallower than Chondrites and Trichichnus.

The deep-sea bathyal settings interpreted for Avetoichnus luisae determined the proposed ethology of the trace maker (probably polychaetes and less probably enteropneusts). Deep-sea environments are characterized by a strong competition for food, especially in the Eocene (Uchman, 2004). Under temporarily better nutrient conditions, the organic-rich sediment was packed in the central core inside the spiral on which microbes were cultivated. The permanently open central core facilitates ventilation of the garden and feeding (Uchman \& Rattazzi, 2011).

\section{AVETOICHNUS LUISAE AT THE IBERIAN PENINSULA}

The record of Avetoichnus luisae in the Iberian Peninsula corresponds to seven specimens from the Zumaia and Gorrondatxe sections (Basque Country, northern Spain), housed in the Departamento de Estratigrafía y Paleontología of the University of Granada.

At the Zumaia section, four specimens were studied (Figs 4, 6): three on parting surfaces observed and collected from the outcrop (bed ZP/E62), and one from a polished section in the laboratory (bed ZP/E56). The specimen occurs at the top part of a marly-calcareous turbiditic bed from the uppermost part of the Palaeocene, just below the Palaeocene/Eocene boundary (Rodríguez-Tovar et al., 2011; Figs 2, 4). Outcrop specimens are endichnial, horizontal, straight structures, showing the characteristic zigzag disposition with spots, which are 1.5-2 mm wide. A tightly-spaced spiral was found to be up to $25 \mathrm{~mm}$ long and 3.5-5 mm wide. The number of helical turns occurring is between six to eight per $20 \mathrm{~mm}$, and they are 1.5-3.5 mm apart. In this section, Avetoichnus luisae co-occurs with a relatively scarce and poorly diversified trace fossil assemblage, mainly registered in the 6-m-thick upper Palaeocene interval (Interval A in Rodríguez-Tovar et al., 2011). From the ichnogenera tentatively differentiated, against a mottled ichnofabric, Planolites is the most abundant ichnotaxon, followed by small Chondrites (probably Chondrites intricatus) and Thalassinoides, while Zoophycos and Scolicia occur occasionally, and large Chondrites (probably Chondrites targionii) is rare.

At the Gorrondatxe section, four specimens (Figs 5, 6) were observed and collected from parting surfaces at the top part of turbiditic marls (beds GO912 and GO915), belonging to the uppermost part of the lower Eocene (near the base of the Lutetian; Early-Middle Eocene boundary). Avetoichnus luisae (described as Helicodromites isp. in Rodríguez-Tovar et al., 2009, 2010; Molina et al., 2011), appears as endichnial, horizontal, straight, tightly-spaced spiral, 2.5-3.5 mm wide, with oval spots, which are 1.5 $\mathrm{mm}$ wide and arranged alternatively. Twelve helical turns are registered per $20 \mathrm{~mm}$. One specimen is preserved as a hypichnial, almost straight double row of very small knobs, which are about $10 \mathrm{~mm}$ long, $1.2 \mathrm{~mm}$ apart, and distributed in an alternating position. At the Gorrondatxe section, Aveitoichnus luisae co-occurs with a moderately diverse trace fossil assemblage. The trace fossil assemblage through the 700 m-thick interval of the Gorrondatxe section consists of 41 ichnospecies belonging to 28 ichnogenera (Rodríguez-Tovar et al., 2010). In the lower part of the succession (Interval A in Rodríguez-Tovar et al., 2010), where Aveitoichnus luisae has been recorded, 22 ichnospecies were recognized; 9 constitute the background assemblage, with a continuous or almost continuous record (Chondrites intricatus, Chondrites targionii, Ophiomorpha annulata, Ophiomorpha rudis, Planolites isp., Scolicia strozzii, Spirophycus bicornis, Thalassinoides isp., and Zoophycos isp.), and 12 of the rest have a more disperse record throughout the succession (Alcyonidiopsis isp. A, ?Cosmorhaphe isp., Desmograpton dertonensis, Helminthopsis abeli, Helminthorhaphe japonica, Multina minima, Paleodictyon miocenicum, Palaeophycus tubularis, Phycosiphon incertum, Protopaleodictyon incompositum, Trichichnus linearis, and ?Urohelminthoida appendiculata). Some forms are exclusive of this interval, such as Alcyonidiopsis isp. A, ?Urohelminthoida, Helminthorhaphe japonica, Multina, Protopaleodictyon, and Paleodictyon miocenicum. 


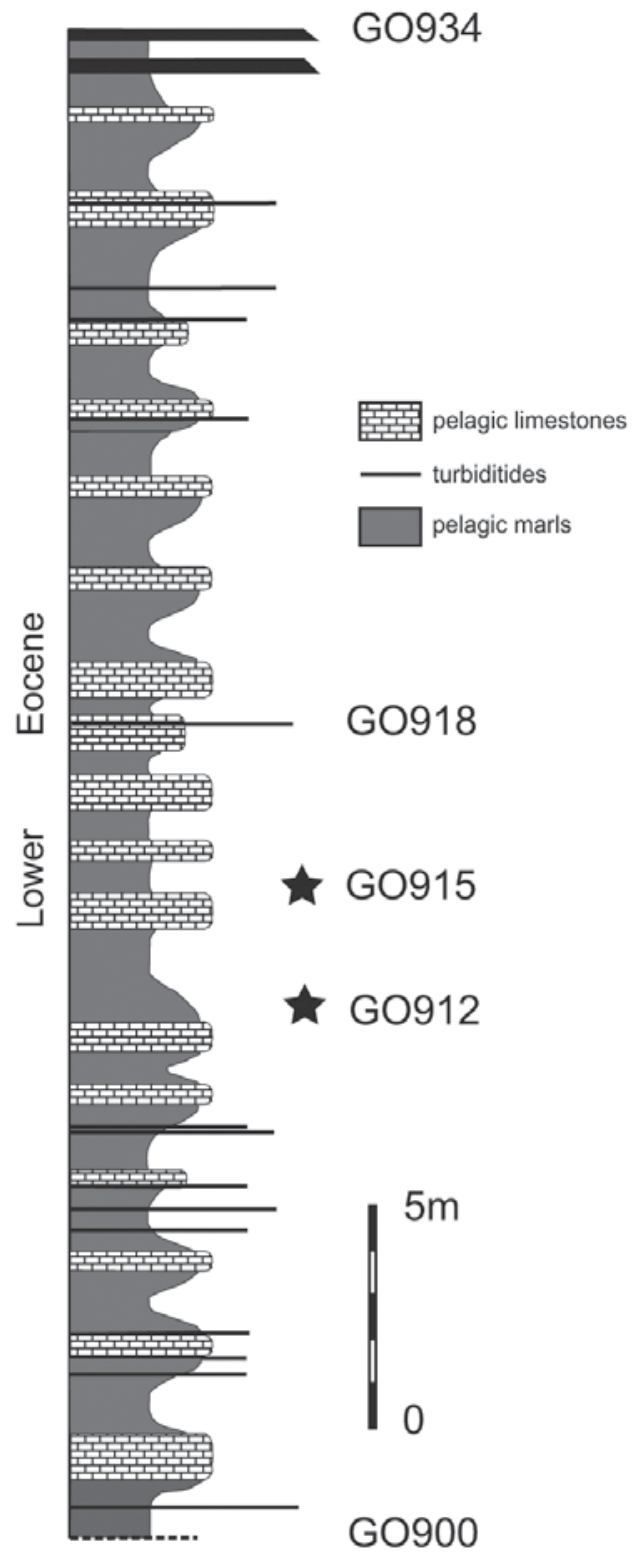

Figure 5. Bed-by-bed detailed log of the lower Eocene interval at the Gorrondatxe section (adapted from Molina et al., 2011), showing ocurrences of Avetoichnus luisae specimens (starts).

\section{PALAEOENVIRONMENTAL CONDITIONS}

During Palaeocene-Eocene times the depositional areas corresponding to the Zumaia and Gorrondatxe sections were part of a broad E-W elongated basin, opened westward to the proto-Bay of Biscay and the North Atlantic Ocean, and thus influenced by northern temperate waters (Ortiz, 1995; Bernaola et al., 2009; Fig. 1). Sediments from the Zumaia section were deposited in offshore areas of the basin, close to the boundary between middle and lower bathyal environments, at about $1000 \mathrm{~m}$ in depth (Pujalte et al., 1998; Bernaola et al., 2007, 2009; Alegret et al., 2009), while the Gorrondatxe section was part of a narrow and deep marine gulf, around $1500 \mathrm{~m}$ in depth (Plaziat, 1981; Pujalte et al., 2002).

Turbidite-poor intervals in the Gorrondatxe section, as the one corresponding to the lower part of the succession, were interpreted to represent periods of high sea-level (Payros et al., 2006, 2009). Thus, the second turbidite-poor interval is correlated as the transgressive system tract of a third-order depositional sequence, followed by a high sea-level stillstand characterized by the progressive increase in hemipelagic limestones close to the top of the second turbidite-poor interval. At the Zumaia section, the uppermost Palaeocene where Avetoichnus luisae was registered could also be related to high sea-levels during development of the depositional sequence DS-6 (Pujalte et al., 1995, 1998).

Trace-fossil assemblage through the Gorrondatxe succession, including the lower part (Interval A), is typical of the deep-sea Nereites ichnofacies, the generalized presence of graphoglyptids being characteristic of the Paleodictyon ichnosubfacies, which is common in distal flysch deposits (Seilacher, 1974; Uchman, 1999). Relatively frequent predepositional trace fossils at interval A, including several types of graphoglyptids, are related to well oxygenated, moderately oligotrophic environments (Rodríguez-Tovar et al., 2010). The variability in the trace maker behaviour -with a predominance of agrichnia but the presence of others such as pascichnia, fodinichnia and chemichnia- as well as in the morphologies of trace fossils, could be related to a limited lateral flux of nutrients due to the scarcity of turbidites and a limited flux of nutrients from the water column (Rodríguez-Tovar et al., 2010). The feeding strategy (microbe gardening or trapping) would be a successful adaptation to nutrient-poor, stable environments (Seilacher, 1977; Miller, 1991; Uchman, 1999, 2003).

At the Zumaia section, the normal, tiered burrowing community developed during the Late Palaeocene, responds to generally good oxygenation and benthic food availability, sufficient to sustain the trace maker community. The local absence of trace fossils and the exclusive presence of a mottled ichnofabric reveals punctual depauperated conditions affecting macrobenthic environment. Towards the top of the uppermost Palaeocene, ichnodiversity and ichnofossil abundance decrease, suggesting a deterioration of environmental conditions for macrobenthic fauna (Rodríguez-Tovar et al., 2011). Latterly, during the earliest Eocene, significant palaeoenvironmental changes determine inhospitable conditions for deep burrowers, probably related to the global rise in temperatures, together with an increase in the flux of organic matter to the sea floor, and a higher rate of oxygen consumption and oxygen deficiency in deep layers of the sediment (RodríguezTovar et al., 2011). 

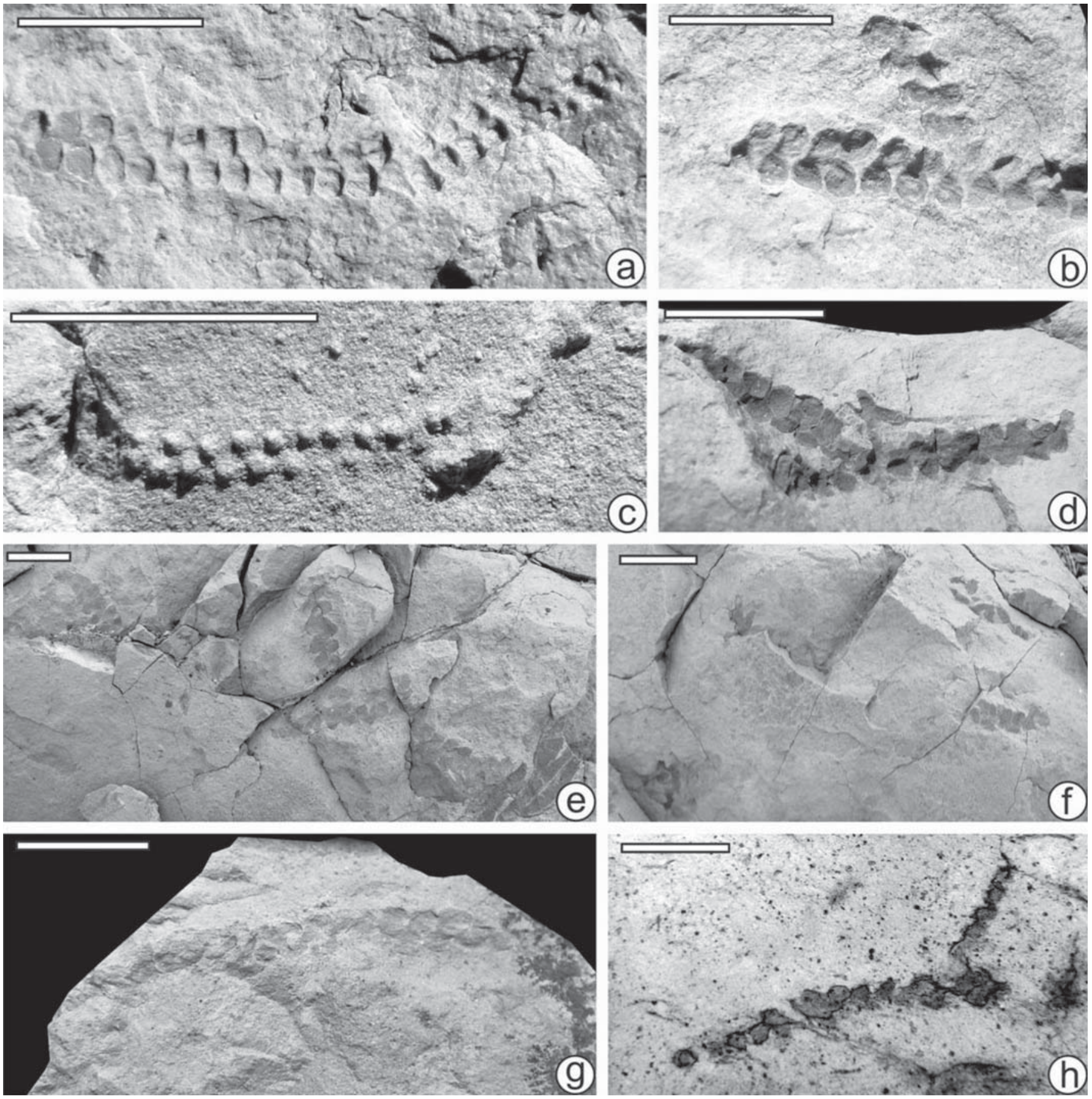

Figure 6. Avetoichnus luisae Uchman \& Rattazzi, 2011 from the Gorrondatxe section (a and c from the bed GO915, b and d from the bed GO912) and the Zumaia section (e-g from the bed ZP/E62, h from the bed ZP/E56), preserved as endichnia on parting surfaces (a-b, d-h) or hypichnia on bedding surface (c). Scale bar $=1 \mathrm{~cm}$. Images $\mathbf{e}$ and $\mathbf{f}$ are outcrop photographs, and $\mathbf{h}$ correspond to a polished surface.

The interpreted palaeoenvironmental conditions dominant during the Late Palaeocene-Early Eocene in the settings corresponding to the Zumaia and Gorrondatxe sections accord with those proposed for Avetoichnus luisae trace maker (Uchman \& Rattazzi, 2011), facilitating its presence, and influencing its behaviour. Depositional settings corresponding to both sections are located in offshore areas at depths from 1000 to $1500 \mathrm{~m}$, where, at least for the Gorrondatxe section, the typical deep-sea Nereites ichnofacies is developed. In both settings, the trace fossil assemblage suggests well oxygenated conditions, meaning that oxygen does not represent a limiting factor for macrobenthic colonization. Low levels of nutrient supply, however, can be interpreted by the comparative diversity and abundance 
of graphoglyptids. Relatively scarce nutrient availability may determine significant competition for food, as seen for deep-sea environments during the Eocene (Uchman, 2004). These moderately oligotrophic conditions could be accentuated during periods of high sea-level, like those prevalent during the activity of Avetoichnus luisae trace maker in the studied settings, pointing to increasing distance from shore and the consequent lower nutrient input from nearshore environments. In the Zumaia section, where graphogliptids are absent and the trace fossil assemblage does not correspond to the deep-sea Nereites ichnofacies, the more unfavourable macrobenthic conditions registered toward the uppermost Palaeocene could be related to a diminution of nutrient input during the interpreted sealevel rise, taking into account the existent well oxygenated environment. Such conditions could determine a farming strategy for Avetoichnus luisae trace maker, revealing the microbial gardening behaviour of the organism.

According to the above, detailed analysis of the record of Avetoichnus luisae in the Iberian Peninsula proves to be of special interest to complement the characterization and interpretation of the recently defined ichnotaxa. Relations with facies and trace-fossil assemblages corroborate the relationship with deep-sea environments, the dominant relatively oligotrophic conditions, and the gardening behaviour of the trace makers, especially during high sea-level conditions.

\section{ACKNOWLEDGEMENTS}

We thank Drs. J.M. de Gibert (Univ. Barcelona), and C. Gaillard (Univ. Lyon 1), for their valuable suggestions and comments on the manuscript. Funding for this research was provided by projects CGL2005-01316/BTE, CGL2008-03007/CLI and RNM-3715, and by the RNM178 Group to F.J. Rodríguez-Tovar and by Jagiellonian University (DS funds) to A. Uchman.

\section{REFERENCES}

Alegret, L., Ortiz, S., Orue-Etxebarria, X., Bernaola, G., Baceta, J.I., Monechi, S., Apellániz, E. \& Pujalte, V. 2009. The Paleocene-Eocene Thermal Maximum: New data on microfossil turnover at the Zumaia section, Spain. Palaios, 24, 318-328.

Baceta, J.I., Pujalte, V., Serra-Kiel, J., Robador, A. \& OrueEtxebarria, X. 2004. El Maastrichtiense final, Paleoceno e Ilerdiense inferior de la Cordillera Pirenaica. In: Geología de España (ed. Vera, J.A.). Sociedad Geológica de España-Instituto Geológico y Minero de España, Madrid, 308-313.

Baceta, J.I., Pujalte, V., Dinarès-Turell, J., Payros, A., OrueEtxebarria, X. \& Bernaola, G. 2000. The Paleocene/Eocene boundary interval in the Zumaia section (Gipuzkoa,
Basque Basin): Magnetostratigraphy and high-resolution lithostratigraphy. Revista de la Sociedad Geológica de España, 13, 375-391.

Bernaola, G., Orue-Etxebarria, X., Payros, A., Dinarès-Turell, J., Tosquella, J., Apellaniz, E. \& Caballero, F. 2006. Biomagnetostratigraphic analysis of the Gorrondatxe section (Basque Country, western Pyrenees): its significance for the definition of the Ypresian/Lutetian boundary stratotype. Neues Jahrbuch für Geologie und Paläontologie, Abhandlungen, 241, 67-109.

Bernaola, G., Martín-Rubio, M., \& Baceta, J.I. 2009. New high resolution calcareous nannofossil analysis across the Danian/Selandian transition at the Zumaia section: comparison with South Tethys and Danish sections. Geologica Acta, 7, 79-92.

Bernaola, G., Baceta, J.I., Orue-Etxebarria, X., Alegret, L., Martín-Rubio, M., Arostegui, J. \& Dinarès-Turell, J. 2007. Evidence of an abrupt environmental disruption during the mid-Paleocene biotic event (Zumaia section, western Pyrenees). Geological Society of America Bulletin, 119, 785-795.

Dinarès-Turell, J., Baceta, J.I., Pujalte, V., Orue-Etxebarria, X. \& Bernaola, G. 2002. Magnetostratigraphic and cyclostratigraphic calibration of a prospective Palaeocene/ Eocene stratotype at Zumaia (Basque Basin, northern Spain). Terra Nova, 14, 371-378.

Miller, W. III, 1991. Paleoecology of graphoglyptids. Ichnos, 1, 305-312.

Molina E., Alegret L., Apellaniz E., Bernaola G., Caballero F., Dinarès-Turell J., Hardenbol J., Heilman-Clausen C., Larrasoaña J.C., Luterbacher H., Monechi S., Ortiz S. Orue-Etxebarria X., Payros A., Pujalte V., RodríguezTovar F.J., Tori F., Tosquella J. \& Uchman A. 2011. The Global Standard Stratotype-section and Point (GSSP) for the base of the Lutetian Stage at the Gorrondatxe section, Spain. Episodes, 34, 86-108.

Ortiz, N. 1995. Differential patterns of benthic foraminiferal extinctions near the Paleocene/Eocene boundary in the North Atlantic and the western Tethys. Marine Micropaleontology, 26, 341-359.

Orue-Etxebarria, X., Lamolda M.A. \& Apellaniz, E. 1984. Bioestratigrafía del Eoceno vizcaíno por medio de los foraminíferos planctónicos. Revista Española de Micropaleontología, 16, 241-263.

Payros, A., Bernaola, G., Orue-Etxebarria, X., Dinarès-Turell, J., Tosquella, J. \& Apellaniz, E. 2007. Reassessment of the Early-Middle Eocene biomagnetochronology based on evidence from the Gorrondatxe section (Basque Country, western Pyrenees). Lethaia, 40, 183-195.

Payros, A., Orue-Etxebarria, X., Bernaola, G., Apellaniz, E., Dinarès-Turell, J., Tosquella, J. \& Caballero, F. 2009. Characterization and astronomically calibrated age of the first occurrence of Turborotalia frontosa in the Gorrondatxe section, a prospective Lutetian GSSP: implications for the Eocene time scale. Lethaia, 42, 255-264.

Payros, A., Orue-Etxebarria, X. \& Pujalte, V. 2006. Covarying sedimentary and biotic fluctuations in Lower-Middle Eocene Pyrenean deep-sea deposits: palaeoenvironmental 
implications. Palaeogeography, Palaeoclimatology, Palaeoecology, 234, 258-276.

Plaziat, J.C. 1981. Late Cretaceous to Late Eocene paleogeographic evolution of southwest Europe. Palaeogeography, Palaeoclimatology, Palaeoecology, 36, 263-320.

Pujalte, V., Baceta, J.I., Dinarès-Turell, J., Orue-Etxebarria, X., Parés, J.-M. \& Payros, A. 1995. Biostratigraphic and magnetostratigraphic intercalibration of latest Cretaceous and Paleocene depositional sequences from the deepwater Basque basin, western Pyrenees, Spain. Earth and Planetary Science Letters, 136, 17-30.

Pujalte, V., Baceta, J.I., Orue-Etxebarria, X., \& Payros, A. 1998. Paleocene strata of the Basque Country, western Pyrenees, northern Spain: Facies and sequence development in a deepwater starved basin. In: Mesozoic and Cenozoic sequence stratigraphy of European basins (eds. de Graciansky, P.C., Hardenbol, J., Jaquin, T. \& Vail P.R.). Society for Sedimentary Geology Special Publication, 60, 311-325.

Pujalte, V., Baceta, J.I., Payros, A., 2002. Chapter 13: Tertiary: Western Pyrenees and Basque-Cantabrian region. In: The Geology of Spain (eds., Gibbons, W. \& Moreno, T.). Geological Society of London, 293-301.

Rodríguez-Tovar, F.J., Uchman, A., Payros, A., Orue-Etxebarria, X., Apellaniz, E. \& Molina, E. (2009): Ichnological analysis through the Ypresian/Lutetian boundary interval at the Gorrondatxe section. In: The Ypresian/Lutetian Transition in the Gorrondatxe Beach (Getxo. Western Pyrenees): Review, Recent Advances and Future Prospects (eds., Orue-Etxebarria, X., Payros, A., Caballero, F., Molina, E., Apellaniz, E. \& Bernaola, G.). University of the Barque Country, Bilbao, 165-171.

Rodríguez-Tovar, F.J., Uchman, A., Payros, A., Orue-Etxebarria, X., Apellaniz, E. \& Molina, E. 2010. Sea-level dynamics and palaeoecological factors affecting trace fossil distribution in Eocene turbiditic deposits (Gorrondatxe section, N Spain). Palaeogeography, Palaeoclimatology, Palaeoecology, 285, 50-65.
Rodríguez-Tovar, F.J., Uchman, A., Alegret, L. \& Molina, E. 2011. Impact of the Paleocene-Eocene Thermal Maximum on the macrobenthic community: Ichnological record from the Zumaia section, northern Spain. Marine Geology, 282, 178-187.

Schmitz, B., Pujalte, V. \& Núñez-Betelu, K. 2000. Climate and sea-level perturbations during the initial Eocene thermal maximum: Evidence from siliciclastic units in the Basque Basin (Ermua, Zumaia and Trabakua Pass), northern Spain. Palaeogeography, Palaeoclimatology, Palaeoecology, 165, 299-320.

Seilacher, A. 1974. Flysch trace fossils: Evolution of behavioural diversity in the deep-sea. Neues Jahrbuch für Geologie und Paläontologie, Monastshefte, 1974, 223-245.

Seilacher, A. 1977. Pattern analysis of Paleodictyon and related trace fossils. In: Trace fossils 2 (eds. Crimes, T.P. \& Harper, J.C.). Geological Journal, Special Issue, 9, 289-334.

Uchman, A. 1999. Ichnology of the Rhenodanubian Flysch (Lower Cretaceous-Eocene) in Austria and Germany. Beringeria, 25, 67-173.

Uchman, A. 2003. Trends in diversity, frequency and complexity of graphoglyptid trace fossils: evolutionary and palaeoenvironmental aspects. Palaeogeography, Palaeoclimatology, Palaeoecology, 192, 123-142.

Uchman, A. 2004. Phanerozoic history of deep-sea trace fossils. In: The application of ichnology to palaeoenvironmental and stratigraphic analysis (ed. Mcllroy, D.). Geological Society, London, Special Publication, 228, 125-139.

Uchman, A. \& Rattazzi, B. 2011. The new complex helical trace fossil Avetoichnus luisae igen. n. et isp. n. from the Cainozoic deep-sea sediments of the Alpine realm: a non-graphoglyptid mid-tier agrichnion. Neues Jahrbuch für Geologie und Paläontologie, Abhandlungen, 260, 319-330.
Manuscrito recibido: 22 de octubre, 2011 Manuscrito aceptado: 2 de diciembre, 2011 